\title{
Health literacy of older people in primary care*
}

\author{
Alfabetização em saúde de pessoas idosas na atenção básica \\ Alfabetización en salud de personas ancianas en la atención básica
Lisiane Manganelli Girardi Paskulin ${ }^{1}$, Carla Cristiane Becker Kottwitz Bierhals², Daiany Borghetti Valer ${ }^{3}$, Marinês Aires ${ }^{4}$, Nara Veras Guimarães ${ }^{5}$, Anemarie Raymundo Brocker ${ }^{6}$, Laís Haase Lanziotti ${ }^{7}$, Eliane Pinheiro de Morais ${ }^{8}$

\begin{abstract}
Objective: To analyze how elderly people linked to health education groups of a primary care unit seek, understand and share information, aiming to maintain and promote health throughout life. Methods: Qualitative descriptive study, conducted with 30 elderlies linked to three groups of health education during the second semester of 2009. The data collection was performed through interviews and thematic analysis with the assistance of the NVivo software. Results: Five categories of analysis were elaborated - Interest/concern in health, search, understanding, sharing and impact of information on the elderly. Conclusions: The health literacy in the groups developed in an individual perspective, focused on the prevention and treatment of injuries, respecting the history and knowledge of the subjects and appreciating the possibilities of exchange among them. The results support the planning, implementation and improvement of actions in health education with older people in primary care.
\end{abstract} Keywords: Health education; Health literacy; Health of the elderly

\section{RESUMO}

Objetivo: Analisar como pessoas idosas vinculadas a grupos de educação em saúde de uma unidade básica de saúde buscam, compreendem e partilham informações a fim de manter e promover a saúde ao longo da vida. Métodos: Pesquisa descritiva de caráter qualitativo, realizada com 30 idosos ligados a três grupos de educação em saúde, no segundo semestre de 2009, cuja coleta de informações deu-se por meio de entrevistas e análise temática, com o apoio do software NVivo. Resultados: Foram elaboradas cinco categorias de análise - interesse/preocupação em saúde; busca, compreensão partilha e repercussão das informações para o idoso. Conclusões: A alfabetização em saúde nos grupos desenvolveu-se em uma perspectiva individual, voltada à prevenção e tratamento de danos, respeitando a trajetória e conhecimento dos sujeitos e valorizando possibilidades de trocas entre os mesmos. Os resultados apoiarão o planejamento, implementação e aprimoramento de ações de educação em saúde com idosos na atenção básica à saúde.

Descritores: Educação em saúde; Alfabetização em saúde; Saúde do idoso

\section{RESUMEN}

Objetivo: Analizar cómo las personas ancianas vinculadas a grupos de educación en salud de una unidad básica de salud buscan, comprenden y comparten informaciones a fin de mantener y promover la salud a lo largo de la vida. Métodos: Se trata de una investigación descriptiva de carácter cualitativo, realizada con 30 ancianos ligados a tres grupos de educación en salud, en el segundo semestre del 2009, cuya recolección de informaciones se llevó a cabo por medio de entrevistas y análisis temático, con el apoyo del software NVivo. Resultados: se elaboraron cinco categorías de análisis - interés/preocupación en salud; búsqueda, comprensión, compartir y repercusión de las informaciones para el anciano. Conclusiones: La alfabetización en salud en los grupos se desarrolló en una perspectiva individual, volcada a la prevención y tratamiento de los daños, respetando la trayectoria y conocimiento de los sujetos y valorizando posibilidades de intercambios entre los mismos. Los resultados apoyaron la planificación, implementación y perfeccionamiento de las acciones de educación en salud con ancianos en la atención básica de la salud. Descriptores: Educación en salud; Alfabetización en salud; Salud del anciano

\footnotetext{
* A study conducted in the Basic health Center LAPI, located in the Northwest district of Porto Alegre city (RS State), Brazil.

${ }^{1}$ PhD in Health Sciences. Associate Professor, School of Nursing, Federal University of Rio Grande do Sul-UFRGS - Porto Alegre (RS). Brazil.

${ }^{2}$ Academic Nursing. Federal University of Rio Grande do Sul-UFRGS - Porto Alegre (RS), Brazil. Fellowship Programme CNPq/PIBIC.

${ }^{3}$ Masters in Nursing, Federal University of Rio Grande do Sul - UFRGS - Porto Alegre (RS), Brazil.

${ }^{4}$ Doctorate in Nursing. Professor of the Nursing Graduation Course, Regional Integrated University of Alto Uruguai and the Missões - URI - Frederico Westphalen (RS), Brazil.

${ }^{5}$ Specialist in Active Ageing. Nutritionist of the Health Center IAPI, Municipality of Porto Alegre (RS), Brazil.

${ }^{6}$ Nurse of the Health Center LAPI, Municipality of Porto Alegre (RS), Brazil.

${ }^{7}$ Nurse of the Health Center LAPI, Municipality of Porto Alegre (RS), Brazil.

${ }^{8}$ PhD in Fundamental Nursing. Associate Professor, School of Nursing, Federal University of Rio Grande do Sul-UFRGS - Porto Alegre (RS), Brazil.
} 


\section{INTRODUCTION}

Health literacy is a relatively new concept in the area of health promotion ${ }^{(1,2)}$ and it is related to the abilities of people to understand aspects of self-care and care in the health system, in order to make appropriate decisions ${ }^{(3)}$. Many times it is used as a synonym of education in health but, although the concepts are related, they have distinct definitions and the literacy can be considered a result of health education. ${ }^{(1)}$.

The health literacy has been widely debated in developed countries, where the basic conditions of life have already been secured. There are several concepts and instruments that assess $\mathrm{it}^{(4)}$, both from a restrict perspective, such as the ability to read prescriptions, as well as from a broad conception, aimed at the ability to make decisions in health ${ }^{(5,6)}$.

In Brazil, the proposition to develop actions in the promotion of health and prevention of harm, as well as the importance of primary care in health, in the attainment of these programs is object of many publications that describe the results of these experiences and interventions ${ }^{(7,8)}$. However, studies that seek the approximation of Brazilian experiences in health education with the concept of health literacy have not yet been disclosed.

The present investigation is based on a benchmark proposed by Canadian researchers ${ }^{(9)}$ and is part of a greater project on healthy ageing in the South region of Brazil. The health literacy is defined as the degree to which people are able to seek, understand and share information to promote and maintain health throughout life ${ }^{(9)}$. It is perceived as a possibility of broadening knowledge and interaction spaces among the actors involved. The instrument that assesses the health literacy proposed by Canadian researchers was adapted to Portuguese ${ }^{(10)}$, and in this article are presented the results of its application on the elderly linked to groups of health education of a Basic Health Unit of Porto Alegre city - RS.

Literature describes that some population groups can be marginalized when it comes to health literacy, such as the ones constituted of older people with low income and low level of education ${ }^{(3,6,11)}$. It also reports that people with low levels of health literacy experience great difficulty in performing self-care in the presence of chronic injuries, and have high rates of hospitalization and premature mortality ${ }^{(11)}$.

The growing proportion of elderly in Brazil increases the demand for health services. In 2010 around $10.7 \%$ of the country population were 60 years and over. In Porto Alegre the age group represented 15.0\% of the population. Comparing the results of the 2000 and 2010 Census it is possible to see that the number of elderly in the capital of Rio Grande do Sul has increased $32 \%{ }^{(12)}$ with even greater variation in some regions of the county. The change of population profile therefore challenges the services and professionals of health primary care responsible for these territories, to deal with the specific needs of this group.

It is also known that work with groups of health education in primary care is an alternative to meet the demands of health promotion in the community, once it acts as a space to build knowledge and critical awareness, also able to help in the autonomy and empowering of individuals with respect to their decisions in health ${ }^{(8)}$.

The study aimed to analyze how older people linked to health education groups of a Basic Health Unit seek, understand and share information in health in order to maintain and promote it throughout life. Thus, it was sought to know the results of actions to promote health in primary care focused on the elderly and to support the assessment and development of projects by managers and service professionals. Nurses are professionals who act in primary care and should develop knowledge and skills to evaluate the actions of health education proposed in this context.

\section{METHODS}

This is a descriptive qualitative study conducted in the Basic Health Unit IAPI, located in the northwest district of Porto Alegre/RS. The Health Center is composed of a Basic Health Unit/BHU (Unidade Básica de Saúde - UBS) and a Specialty clinic. The unit comprises an area composed of seven districts, with a total area of $13.66 \mathrm{~km}^{2}$ and a registered population of over 60 thousand people. It is a region with one of the highest proportions of elderly in the municipality and with quite heterogeneous socioeconomic conditions.

The study included 30 people aged 60 years and over that attended a Seniors Group, a Climacteric Group or the Hiperdia Group (Hiperdia is a Brazilian national system of registration for hypertensive and diabetic people). These three groups are traditional in the service and promote weekly or biweekly meetings with the registered users, composed mostly of older people. The number of respondents was intentionally defined and ten people from each of the abovementioned groups were heard. In order to select the participants, two researchers followed one meeting of each of the three groups. On this occasion the research project was explained and the members were invited to participate in the study. People interested in taking part gave their names, addresses and phone numbers for the posterior scheduling of the interview.

During the process of questionnaire application four elderlies were excluded because they no longer belonged 
to the group and two for being away travelling during the period of collection. The interviews were conducted during the second semester of 2009 until the number of participants was reached. All interviews were recorded and transcribed.

For the data collection it was used an instrument composed of open-ended and closed-ended questions, elaborated by Canadian researchers ${ }^{(9)}$ and adapted for use in Brazil ${ }^{(10)}$. The questions start with an interest/ concern in health experienced and chosen by the participant, who responds to questions based on a concrete situation ("Over the last month what have you thought about your health?”).

The remaining questions dealt with the respondents 'comprehension, the health situation chosen and the doubts about it. The information sources used for cases were related to the situation, the satisfaction and the utility of information, the comprehension, the coherence, the sharing and the impact of data in their lives. The closed-ended questions assessed the satisfaction and understanding of health information by the elderly using a Likert Scale and reinforcing the opinions expressed in the open-ended questions. The answers obtained in the closed-ended questions were not presented in this article.

Initially the users included in the study were characterized according to gender, age, level of education, income, housing and time of participation in his/her group. Later on, the interview described above was applied. The thematic analysis of the open-ended questions was done and used as pre-categories the questions that compose the instrument in three stages: pre-analysis, material exploration and interpretation of results ${ }^{(13)}$. The software Qualitative Solutions Research NVivo (QSR NVivo) 2.0 was used. The categorization process was carried out separately by two groups of researchers for posterior crossing of analysis, which ensures the reliability of the survey.

The research Project was approved by the Ethics Committee of the Municipality of Porto Alegre (Case $\mathrm{n}^{\mathrm{o}}$ 001.029435.08.0) and by the Ethics Committee in Research of the Federal University of Rio Grande do Sul/UFRGS (number.2007819). Participants signed a Term of Consent. The anonymity of the participants was ensured therefore acronyms were used on the presentation of the speeches.

\section{RESULTS}

Among the respondents, 27 were women, aged 73 years old on average. The average scholarity was eight years of studies. The elderly had an average family income of 1.9 minimum wages. The majority affirmed to live with relatives and to own a house. The time in health education groups ranged between eight and 12 years, with a median of ten years of participation.

In order to achieve the objective of the study, five categories were organized, based on the analysis of the answers to the open-ended questions. The speeches of the elderly were joined by subject areas in each of the classifications (Table 1).

Table 1. Categories of analysis and subject areas

\begin{tabular}{|c|c|}
\hline Categories & Subject areas \\
\hline Interest/concern in health & $\begin{array}{l}\text { Chronic damage; Strategies } \\
\text { for damage prevention and } \\
\text { health promotion; Signs/ } \\
\text { symptoms; Social aspects. }\end{array}$ \\
\hline Search for information & $\begin{array}{l}\text { Causes; Diagnosis; } \\
\text { Promotion/prevention; } \\
\text { Complications; Treatment; } \\
\text { Prognostic; Initially with no } \\
\text { doubts. }\end{array}$ \\
\hline Information understanding & $\begin{array}{l}\text { Understanding of } \\
\text { information; Disagreement } \\
\text { of information; Words they } \\
\text { did not understand; What the } \\
\text { elderly did when words were } \\
\text { not understood. }\end{array}$ \\
\hline \multicolumn{2}{|l|}{ Sharing information: } \\
\hline $\begin{array}{l}\text { With whom the elderly talked } \\
\text { about their concerns in health }\end{array}$ & $\begin{array}{l}\text { Family; Groups of the health } \\
\text { service; Community groups; } \\
\text { Nobody; Not reported. }\end{array}$ \\
\hline $\begin{array}{l}\text { The most important health } \\
\text { information to come to the } \\
\text { knowledge of other elderly }\end{array}$ & $\begin{array}{l}\text { Search for information about } \\
\text { the disease conditions; Find } \\
\text { ways to change lifestyle/ } \\
\text { health behavior; Do } \\
\text { preventive exams and go to } \\
\text { consultations for prevention } \\
\text { through medication, } \\
\text { consultations and exams; Not } \\
\text { reported. }\end{array}$ \\
\hline $\begin{array}{l}\text { To whom the elderly told what } \\
\text { they have learnt }\end{array}$ & $\begin{array}{l}\text { Family; Groups of the health } \\
\text { service; Friends of the } \\
\text { group; Community group; } \\
\text { Friends; Neighbors; Strangers; } \\
\text { Nobody; Not reported. }\end{array}$ \\
\hline $\begin{array}{l}\text { Impact of information on the } \\
\text { elderly }\end{array}$ & $\begin{array}{l}\text { It made a difference in the } \\
\text { lives of the elderly as it } \\
\text { brought changes to the family; } \\
\text { Improved the self-care; It made } \\
\text { a difference because the person } \\
\text { had the same problem and } \\
\text { identified with the situation; } \\
\text { It made no difference; Unable } \\
\text { to inform; Not shared; Not } \\
\text { reported. }\end{array}$ \\
\hline
\end{tabular}

\section{Interest/concern in health}

As reported on the section "Methods", the development of the interview started with an interest/concern in health defined by the participant. The data on Table 2 shows the majority of the respondents mentioned interests linked to the strategies of damage prevention and health promotion. Some mentioned signs and symptoms such as sciatic, knees and back pain; others 
Table 2. Interest/concern in health

\begin{tabular}{|lcl|}
\hline Subjects & Number of answers* & Most frequent answers \\
\hline $\begin{array}{l}\text { Strategies of damage prevention and health } \\
\text { promotion }\end{array}$ & 41 & $\begin{array}{l}\text { Care with food; Physical exercise; Proper use of } \\
\text { medication; Realization of exams. }\end{array}$ \\
Chronic damages & 24 & Hypertension; Osteoarthritis; Dyslipidemia. \\
Signs and symptoms & 8 & Pain \\
Social aspects & 3 & Family situations \\
No thoughts & 1 & \\
\hline
\end{tabular}

* The number of answers was higher as the elderly reported more than one interest/concern in health.

reported concern with aspects related to work and family issues. It is noteworthy that the elderly mentioned more than one interest/concern in health.

To follow up the interview the elderly were invited to choose just one of the interests/concerns in health they have mentioned previously. Among all the participants, 14 chose to talk about a chronic injury and 15 chose strategies focused on the damage prevention and health promotion or about a sign/symptom reported. One of the 30 seniors affirmed not to have thought about his health in the past month and the interview was carried out without the support of a concrete situation.

As for the meaning attributed to the chosen situation, just under half ${ }^{(13)}$ addressed its impact in their lives:

[... I couldn't get around, you know? That's my problem, I really wish I could walk around [...] for one year I've been walking with the stick [...](Elderly 9).

Other seniors (13) explained how the interest/concern was related to their health:

[...] To watch the diet is to avoid fried food, as much as possible, soda, sweets that I know it turns into fat. Bread I'm used to have always wholegrain, skimmed milk [...] (Elderly 29).

It also drew the attention that three elderlies were not able to explain what the chosen situation meant.

\section{Search for information}

In this category are grouped the answers related to the search for information regarding one's interest/ concern in health.

When asked if there were doubts about the health situation chosen, the majority stated not to be informed about the causes of health conditions (9) and on aspects of prevention of complications (8). Doubts regarding the diagnosis, the complications, the treatment and the prognosis were also reported (6). Others reported not to have had doubts or just did not report.

To get information on the issues raised, the participants reported their sources to be, above all, the health professionals, more frequently the physicians, followed by nurses, nutritionists and physiotherapists. Among all the sources mentioned, nearly half of the professionals were linked to the Basic Health Unit or the clinic where the study was conducted. The other participants mentioned professionals of the specialty clinic of the service itself, of other clinics linked to hospital services or of their personal health insurance services that they used for consultation with specialists. They also related as another source, although less frequently, the health service groups and community groups, the media, books, friends and family.

\section{Information understanding}

In this category were included the answers related to the understanding of information, the disagreement among data provided, the words not understood by the elderly at the time of receiving information and their reactions due to incomprehension.

Regarding the understanding of information, a large part of the users classified it as of easy comprehension. Despite that, some elderly highlighted that the information provided was only related to the diagnosis and the treatment of the concern in health, or, in other words, was restricted and did not detail aspects considered important by them:

\section{[...] She hasn't told me much about the pain, you know?} [...] (Elderly 2).

One elderly reported to have never understood the cause of the health situation chosen, while other affirmed not to have subsidies in health to take the matter into consideration.

[...] Difficult because I never understood why [...] (Elderly 16).

Great part of the respondents (22) reported to not have observed the discrepancy among information received from the several sources used. But the disagreement of information became explicit on the testimony of some (4):

[...] Yeah, sometimes the doctor says something and then in the group it's not like that, you know? This has happened [...] (Elderly18).

When questioned if during the supply of information they heard words they did not understand, a great part (21) also answered no. The others (8) reported situations in which they heard words with meanings they did not know and affirmed that in such cases they asked again. 
[...] Ask him (the doctor) to open the range so the person can understand, you know what I mean? The lay person doesn't understand everything and sometimes words, people accustomed to this methodology [...] then you have to ask again [...] (Elderly 8).

\section{Sharing of information}

In this category were grouped questions related to sharing of information with other people, the knowledge that the elderly consider as the most important to share with others and if this information made a difference to who received it.

The majority (25) reported to have shared the concern in health with the family. A smaller group (5) commented about the concern in health also with participants of health service groups, while others also cited the coexistence groups such as friends and neighbors. Only a few participants (2) reported to not have shared the information of concern in health with anybody.

I didn't speak. Just about taking medication for the blood pressure, but it's not something that concerns the others, right? (Elderly 27).

When asked which would be the most important information about the health situation chosen that should come to the knowledge of the other seniors, the majority (25) pointed out the ways of changing lifestyle and/or health behavior, aiming to minimize the already existing problems. For example, they cited the adoption of healthy eating habits, the search for ways to preserve the memory, physical activity practice, quit smoking, search for wellbeing, do what one likes and keep active. They also reported that healthy habits must be kept from an early age and throughout the entire life as highlighted by the following speech:

[...] I think we have to, should even start from young, to have some kind of care [...] (Elderly 28).

The report of some participants (5) also shows that the most important aspects for other seniors to be aware of, are related to a deeper understanding of the condition of an established disease: what it is, the cause, how the diagnosis is done, the treatments and how to prevent complications.

[...] To know why (the disease), what are the grounds [...] (Elderly 16).

Just over half of the respondents (16) revealed that, when sharing information about the health situation with their families, changes in behavior were noticed. These changes occurred in the relationships between the elderly and their families - based on the understanding of the situation experienced by the senior - and in the relationship of the relatives with their own healths, as they also started to take more care of themselves.

[... I think so, hub? Because they have learnt to eat better than myself. I think it did make a difference [...] (Elderly 5).
They also stressed that sharing the knowledge gave them the opportunity to divide the experienced situation with people alike in the groups:

[...] Some have already told me they had experiences like that, some had it too, and we exchange ideas, on how we felt […](Elderly 30)

On the other hand, some elderly (7) affirmed that the shared information made no difference on the lives of the people with whom they divided their learning:

They don't let it make a difference (Elderly 21).

\section{Impact of information on the elderly}

Were included in this category the analyzed answers to the questions about the impact of information on the lives of the elderly. The statements of the majority involved (25) show that the subsidies sought/received have improved one's health conditions and their self-care.

[...] I have learnt to take better care of my body and I always try to pass this on [...] (Elderly 26).

Some participants also demonstrated that, based on information received, there was greater acceptance of the health situation, as well as the perception of wellbeing, self-confidence in the care with health and improvements in the social interactions.

[...] The only thing is that we have to comply with it, to learn to live with it [...] (Elderly 28).

I feel lighter and safer to be doing everything right, I mean, it's very hard to say you're doing it right but I try to do it (Elderly 12).

It changed a lot [...] it brought me a bigger friendship circle (Elderly 26).

However, one participant reported that the fact of having more information made her tenser and more preoccupied with her own health:

[... It changed because I got tenser, more nervous, more worried [...] (Elderly 15).

But for five participants the information sought/ received had no impact on their lives, either because they already knew it or because it had no influence in their way of life.

[...] It hasn't changed at all, it was the same as I already knew [..] (Elderly14).

\section{DISCUSSION}

In the results presented on the characterization of the subjects, it was found that there were elderly groups which still participated of the health education activities, a key factor to keep an active aging and a support network. It also drew the attention the income and the average time of studies (scholarity) of the investigation participants. Both were higher than the average of the region where the survey was conducted ${ }^{(14)}$ and than the Brazilian reality, which certainly influenced in the results of health literacy here described. It is known 
that socioeconomic conditions are determinant factors for health and they also favor the literacy in this area ${ }^{(15)}$.

Unlike the results obtained in the Canadian study ${ }^{(9)}$, in which the health situations chosen by the elderly were essentially about chronic damages, the main situations chosen by the elderly subject of this study included strategies of damage prevention and health promotion. It was also found that watching the diet was isolatedly, the most cited answer in the strategy of damage prevention and health promotion. This finding may be related with the experience of the elderly in group activities that have a team formed by nurses, social workers and physicians, professionals responsible for deeply exploring these matters.

As described in the article that discussed the adaptation of the instrument for use in Brazil, one question was incorporated to the Brazilian version and it addresses the meaning of the health situation chosen by the elderly ${ }^{(10)}$. It was noticed that part of the elderly was unable to explain what it meant and gave more value to the impact in their lives brought by the situation than the actual understanding of it. During the interviews it was noticeable that the elderly build a story about the disease or its prevention in order to comprehend what is happening with their health, an interpretation based in culture and personal values, hence, different than a clinic point of view.

The doubts the elderly had, and to which they looked for information in health were similar to the ones exposed by the Canadian authors ${ }^{(9)}$. However, the variety of information searched by the participants of the Canadian research were broader, including current news on chronic damages of interest, the meaning of exam results and guidance to seek assistance in the health care network. Apparently the doubts described by the elderly in the present study were more basic, which may indicate compliance with information and a lower requirement for depth. Another factor that may have influenced these differences was schooling, higher among Canadians, as well as the access to an expanded health care network, which also favors questioning.

As for the sources of information, the highlights were on health professionals, more frequently mentioned by the respondents. In the Canadian study though, the search for information on the media, in books and pamphlets was also quite mentioned. Contact with these sources in the Brazilian context is still very limited but may represent an important alternative for the future based on digital inclusion.

Many elderly highlighted that the information received was quite limited, related to the diagnosis and the treatment, while the doubts reported were broader and unclear, showing that the education in health of the elderly has to be taken to a deeper level. Knowledge can be a means of personal empowerment and control of the individual over his/her own health ${ }^{(16)}$. In order to support the decisions in health and changes in the life context of the individuals, information must be accessible and adapted to the needs of the users, in accordance with the social and cultural context in which they are inserted ${ }^{(1,17)}$.

The small occurrence of discrepancy in information provided by different sources is considered positive, as well as the position assumed by the elderly of questioning the sources of information in case some word is not understood. However, health professionals must be aware of these situations, seeking to adapt the vocabulary and clarify possible discrepancies reported by the users.

Regarding sharing the information on the chosen health situation, it stands out the importance of the family, as well as of the members of health education groups. The results obtained showed that health education had impact both on the participants of the study and their families, and possibly on their peers.

When asked about what would be the most important information to come to the knowledge of the other elderly (regarding the health situation chosen) basically all of them reported aspects related to the adoption of a healthy behavior, aiming to minimize the already existing problems. These findings refer to the indexes of active ageing proposed by the World Health Organization in which quality of life at an old age depends on several factors, among them, the experience when faced with risks and opportunities throughout life ${ }^{(18)}$. Considering the aging of the Brazilian population, these guidelines should be effectively addressed and, as one elderly reminded, at one stage prior to the old age. Therefore, the groups are an efficient strategy to be implemented for the education in health.

Regarding the implications of the information to the elderly, it was also observed that the sought/received data brought benefits to the majority of the participants, with impact on the health status, on the ability to perform self-care and live better. These observations, together with other studies regarding the importance of assessing the literacy in health, were able to implement actions of health education in the area ${ }^{(19)}$.

It is noteworthy that an elderly with bellow average scholarity was unable to identify a situation in health, making it difficult to conduct the remaining questions. This participant was kept in the study, although his answers were limited because the fact can demonstrate a difficulty of the elderly to respond to more complex issues, which can happen again in other studies that replicate the investigation described here, especially if conducted with people with low level of education. Certainly these people require special attention from the formal support network ${ }^{(20)}$ and their informal network will have to be assisted by health professionals in order to help these seniors to maintain or improve their health. 
Another issue to be stressed, similar to one described by the Canadian researchers, was during the stage of interview analysis, the challenge to separate the experiences of the elderly in search for health care from the experiences related to health literacy.

It is noteworthy that the concept of health literacy used, that was based on the Canadian benchmark, aimed to assess it from a critical perspective ${ }^{(1,9)}$, despite the inclusion of an individual conception. Although not possible to analyze the impact of education in health in an expanded context of reality change, this reference considers the trajectory and the previous knowledge of the subjects without leaving them in a passive perspective. Thus, it is believed that the obtained results may subsidize the nurses and other primary care professionals in the interventions performed by them, bringing benefits to this emerging population group and taking its peculiarities into consideration. Other forms of assessment may be used in order to complement and extend the proposed perspective.

In the context of care, the results may support the planning, the implementation and the improvement of health education actions with the elderly in the services of health primary care. The nurse as an agent of actions in health education may use the health literacy to develop and evaluate the projects performed in the local context.

Faced with an aging population scenario, the study allowed an analysis on how the elderly search, under-

\section{REFERENCES}

1. Nutbeam D. Health literacy as a public health goal: a challenge for contemporary health education and communication strategies into the 21st century. Heath Promot Int. 2000; 15(3): 259-67.

2. World Health Organization. Health promotion glossary [Internet]. Geneva: WHO; 1998. [cited 2012 Feb 10]. Available from: http://www.who.int/healthpromotion/ about/HPR\%20Glossary\%201998.pdf

3. Cutilli C. Health literacy in geriatric patients: an integrative review of the literature. Orthop Nurs. 2007; 26(1):43-8.

4. Abel T. Measuring health literacy: moving towards a health promotion perspective. Int J Public Health. 2008; 53(4):169-70.

5. Nutbeam D. The evolving concept health literacy. Soc Sci Med. 2008; 67(12): 2072-8.

6. Peerson A, Saunders M. Health literacy revisited: what do we mean and why does it matter? Health Promot Int. 2009; 24(3): 285-96.

7. Albuquerque PC, Stotz EN . [Popular education in primary care: in search of comprehensive health care]. Interface (Botucatu). 2004; 8(15): 259-74. Portuguese.

8. Souza AC, Colomé IC, Costa LE, Oliveira DL. A educação em saúde com grupos na comunidade: uma estratégia facilitadora da promoção da saúde. Rev Gaúcha Enferm. 2005; 26(2):147-53.

9. Kwan B,Frankish J, Rootman I. The development and validation of measures of "health literacy" in different populations. Columbia: University of British Columbia, Institute of Health Promotion Research; 2006.

10. Paskulin LM, Aires M, Valer DB, Morais EP, Freitas IB. Adaptation of an instrument to measure health literacy of stand and share health information that promotes self-care. It is noteworthy that these elderly had a differentiated level of education (scholarity) and besides that, participated of health education groups, what might have influenced the results. Thus, studies with users not linked with groups and with different levels of education might be conducted, in order to compare the results already obtained.

The results of this study were presented to the research subjects, to the community and to the health professionals during the celebration of "The week of the elderly" in the Basic Unit of the Health Center IAPI. This allows the return to the community of their contribution with the research conduction, just as it can stimulate users and professionals to reflect on the possibilities of enlargement of spaces to build the autonomy in a collective perspective.

\section{FINAL CONSIDERATIONS}

Guided by the analysis of the answers of the elderly, five categories were identified: interest/concern in health, search, understanding, sharing and impact of information on the elderly. The health literacy in the groups was developed from an individual perspective, respecting the knowledge and history of the subjects and enhancing the possibilities of exchanges among them. older people. Acta Paul Enferm. 2011; 24(2): 271-7.

11. Baker DW, Wolf MS, Feinglass J, Thompson JA, Gazmararian JA, Huang J. Health literacy and mortality among elderly persons. Arch Intern Med. 2007; 167(14): 1503-9.

12. Instituto Brasileiro de Geografia e Estatística. Primeiros dados do censo 2010. Dados: Brasil [Internet] [citado 2011 Dez 20). Disponível em: http://www.ibge.gov.br/ censo2010/primeiros_dados_divulgados/index.php

13. Minayo MC. Fase de análise ou tratamento do material. In: Minayo MC. O desafio do conhecimento: pesquisa qualitativa em saúde. 8a ed. São Paulo: Hucitec; 2004. p.197-247.

14. Paskulin LM, Vianna LA. [Sociodemographic profile and selfreferred health conditions of the elderly in a city of Southern Brazill. Rev Saúde Pública. 2007; 41(5): 757-68. Portuguese.

15. Kickbusch,IS. Health literacy: addressing the health and education divide. Health Promot Int. 2001; 16(3): 289-97.

16. Rootman I, Ronson B. Literacy and health research in Canada: where have we been and where should we go? Can J Public Health. 2005; 96 Suppl 2:S62-77.

17. Ishikawa H, Kiuchi T. Health literacy and health communication. Biopychosoc Med. 2010; 4:18.

18. Organização Mundial da Saúde. Envelhecimento ativo: uma política de saúde. Tradutor Gontijo S. Brasília (DF): Organização Pan-Americana de Saúde; 2005.

19. Chang M, Kelly AE. Patient education: addressing cultural diversity and health literacy issues. Urol Nurs. 2007; 27(5): 411-7.

20. Clark DO, Frankel RM, Morgan DL, Ricketts G, Bair MJ, Nyland KA, et al. The meaning and significance of selfmanagement among socioeconomically vulnerable older adults. J Gerontol B Psychol Sci Soc Sci. 2008; 63(5):S312-9. 